\title{
Retinoid and Ethanol-Sensitive $\operatorname{Benzo}(\alpha)$ Pyrene Induction of Cytochrome P450 in Human Keratinocytes
}

\author{
John J. Wille ${ }^{1^{*}}$, Jong Y. Park ${ }^{2}$ \\ ${ }^{1}$ Bioderm Technologies, Inc., Chesterfield, USA; ${ }^{2}$ Division of Cancer Prevention and Control, Moffitt Cancer Center, Tampa, USA. \\ Email: *jjwille@aol.com
}

Received October $26^{\text {th }}, 2012$; revised November $28^{\text {th }}, 2012$; accepted December $7^{\text {th }}, 2012$

\begin{abstract}
Polycyclic aromatic hydrocarbons (PAHs) induce cytochrome P-450 monoxygenase enzymes that catalyze the formation of DNA adducts. We investigated the effects benzo $(\alpha)$ pyrene $(\mathrm{B}[\alpha] \mathrm{P})$ alone or in combination with ethanol on normal human keratinocyte (NHK) growth, induction of cytochrome P-4501A1 (CYP1A1), and modulation of these treatments by retinoic acid (RA) in a serum-free culture medium. Growth-arrested confluent NHK serum-free cultures were treated with $\mathrm{B}[\alpha] \mathrm{P}$ alone or in combination with ethanol and RA. The effects on CYP1A1 enzyme activity were investigated. $\mathrm{B}[\alpha] \mathrm{P}$ treatment alone was not toxic to post-confluent cells; sub-toxic ethanol stimulated cell growth regardless $\mathrm{B}[\alpha] \mathrm{P}$ treatment. No CYP1A1 activity was detected in control or ethanol-treated NHK cell cultures. $\mathrm{B}[\alpha] \mathrm{P}$ alone induced CYP1A1 activity, and $\mathrm{B}[\alpha] \mathrm{P}$ plus ethanol treatment further enhanced $\mathrm{B}[\alpha] \mathrm{P}$-induced CYP1A1 activity. Pretreatment with all-trans-RA (t-RA) abolished ethanol enhancement of CYP1A1 activity. There is a synergistic action of ethanol in combination with PAH on induction of P-450 cytochrome enzymes. By contrast, RA reverses ethanol enhancement implying a role for retinoid therapy in counteracting the risk posed by combined alcohol and PAH exposure on epidermal cell carcinogenesis.
\end{abstract}

Keywords: CYP1A1; Aryl Hydrocarbon Hydroxylase; Benzo $(\alpha)$ Pyrene; Ethanol; Keratinocytes, Retinoids

\section{Introduction}

Polycyclic aromatic hydrocarbons (PAHs) including benz $(\alpha)$ pyrene $(\mathrm{B}[\alpha] \mathrm{P})$ are well-known environmental pollutants. They can undergo metabolic activation to potent ultimate carcinogens by mean of cytochrome P450 monooxygenase enzymes that catalyzes the bioactivation of many procarcinogens [1]. A key metabolic enzyme in skin is aryl hydrocarbon hydroxylase (AHH), a monooxygenase enzyme. In particular, cytochrome P450 1A1 (CYP1A1) catalyzes the conversion of PAHs, such as $\mathrm{B}[\alpha] \mathrm{P}$ into potent carcinogens and mutagenic agents. Human epithelial tissues possess a family of mixed functional oxidases and related enzymes [2], which convert PAH type procarcinogens to ultimate carcinogens [3]. These enzymes convert $\mathrm{B}[\alpha] \mathrm{P}$, found in tobacco smoke to an ultimate carcinogen $\mathrm{B}[\alpha] \mathrm{P}-7,8$-dihydrodiol, 9,10 epoxide $[4,5]$. Prior studies have reported the induction of CYP1A1 activity by application of $\mathrm{B}[\alpha] \mathrm{P}$ in human skin [6], in a variety of normal cultured epidermal cells, including squamous carcinoma cells [7-9]. $\mathrm{B}[\alpha] \mathrm{P}$ was shown to induce CYP1A1 mRNA in rodent epidermis

*Corresponding author. and cultured human epidermal keratinocytes [10,11], cell transformation [12] and immortalization of human mammary epithelial cells [13]. We and others previously have demonstrated a significant association between CYP1A1, alcohol consumption, tobacco use and cancer of the oral cavity [14-16]. Therefore, we decided to reexamine the question of alcohol effects on PAH induced CYP1A1 enzymes in normal human foreskin keratinocytes (NHKs) and to further elucidate the role of retinoids in mediating these effects. Retinoids have been suggested as chemoprevention agents because retinoids are known as a regulator of cell growth, differentiation, proliferation, and apoptosis [17-22]. Zhou et al. (2010) reported significant attenuation of BP-induced DNA adducts by RA in human hepatoma cells [18]. Further, we demonstrated that vitamin A-deficient animals are more susceptible to PAH-induced carcinogenesis [21]. Recently, Ramya et al. (2012) demonstrated anti-cancer effect of all trans retinoic acid during $\mathrm{B}[\alpha] \mathrm{P}$ induced lung cancer development in BALB/c mice. RA supplementation decreased lipid peroxides (LPO), lipid hydroperoxides (LOOH) and nitric oxide (NO) with concomitant increase in the levels of tissue anti-oxidants like superoxide dismutase (SOD), catalase (CAT), glutathione peroxidase (GPx), induced 
glutathione $(\mathrm{GSH})$ and vitamin $\mathrm{C}$ during $\mathrm{B}[\alpha] \mathrm{P}$-induced lung carcinogenesis [22].

Here we present the results of studies on the induction of CYP1A1 by $\mathrm{B}[\alpha] \mathrm{P}$ in serum-free post-confluent monolayer cultures of NHKs. Further, we examined the individual and combined effect of low doses of ethanol, and retinoic acid (RA) on $\mathrm{B}[\alpha] \mathrm{P}$-inducible $\mathrm{AHH}$ activity. A significant enhancement of $\mathrm{B}[\alpha] \mathrm{P}$-induced CYP1A1 enzyme activity by low doses of ethanol was observed and this enhanced or superinduction phenomenon was abrogated by pre-treatment with RA.

\section{Materials \& Methods}

\subsection{Materials}

Epidermal growth factor (EGF), insulin, dimethylsulfoxide (DMSO), $\mathrm{B}[\alpha] \mathrm{P}$ and all-trans-RA (all-t-RA) were purchased from Sigma Chemical Company (St. Louis, MO). Serum-free culture medium MCDB 153 basal medium was purchased from InVitrogen (Cascade Biologics, Seattle, WA). Stock solutions of B $[\alpha] \mathrm{P}$ and all-t-RA were each dissolved in DMSO.

\subsection{Cell Culture}

Primary and serial passage cultures of NHK were propagated in serum-free medium and cell counting methods were performed as we previously published [23]. NHK cells were plated at an initial cell density of $3 \times 10^{3}$ cells $/ \mathrm{cm}^{2}$ in plastic disposable $25 \mathrm{~cm}^{2}$ or $75 \mathrm{~cm}^{2}$ sterile culture dishes.

\subsection{Effect of Ethanol, $B[\alpha] P$ and Retinoic Acid on AHH Induction}

The individual and combined effects of ethanol, $\mathrm{B}[\alpha] \mathrm{P}$ on the viability and growth of NHK was investigated in post-confluent monolayer cultures propagated in low calcium $(0.1 \mathrm{mM})$ serum-free MCDB 153 medium supplemented with EGF $(5 \mu \mathrm{g} / \mathrm{ml})$ and insulin $(5 \mu \mathrm{g} / \mathrm{ml}$ insulin). Confluent monolayers were exposed for 24 hours a $\mathrm{CO}_{2}$ incubator at $37^{\circ} \mathrm{C}$ with various concentrations of ethanol ranging from $0.5 \%$ to $2.0 \%(\mathrm{v} / \mathrm{v})$ alone or in combination with $5 \mu \mathrm{g} / \mathrm{ml}$ of $\mathrm{B}[\alpha] \mathrm{P}$ in the presence or absence trans-RA $\left(1 \times 10^{-8} \mathrm{M}\right)$. At the end of all treatments cell suspensions were prepared, and cell concentrations, total cell yields and cell viability were assayed as we previously described [23]. The effects of various treatments on the viability and morphology of livetreated cultures were recorded using a Nikon Optiphot inverted phase contrast microscope. Cell viability in cell suspensions was obtained by in Trypan Blue dye exclusion assay as we described [24].

\subsection{Enzyme Assays}

NHK cell cultures were rinsed twice with pre-warned $1 \times$ PBS, $\mathrm{pH}$ 7.4, and prior to preparation of cell extracts. Microsomes from NHK cells were prepared as we published with a slightly modified procedure [25]. Briefly six to eight plates from each set of treatments were harvested by scrapping the cells from the underlying plastic substratum in ice-cold phosphate buffered saline. Untreated and treated cells were centrifuged at $1000 \times \mathrm{g}$ for 5 minutes and resuspended in hypotonic buffer $(10 \mathrm{mM}$ $\mathrm{KCl}, 0.5 \mathrm{mM}$ EDTA in $10 \mathrm{mM}$ Tris, $\mathrm{pH} 7.4$ ) at a final concentration of $1 \times 10^{7}$ cells $/ \mathrm{ml}$. The cells are swelled for 10 minutes on ice followed by the addition of an equal volume of homogenizing buffer, and homogenized by several passes in a Teflon-glass homogenizer, and centrifuged for 20 minutes at $9000 \times \mathrm{g}$, and the resulting supernatant for 45 minutes at $100,000 \times \mathrm{g}$. The microsomal pellets are washed with $10 \mathrm{mM}$ Tris- $\mathrm{HCl}(\mathrm{pH}$ 7.4) in $0.25 \mathrm{M}$ sucrose, resuspended in 2 volumes of this medium, and stored frozen at $-80^{\circ} \mathrm{C}$ until assayed. Microsomal CYP1A1 activity was measured by a modified procedure [26]. Protein level is estimated according to the method of Lowry [27].

\subsection{Experimental Design}

The methods table below presents the experimental design for the results shown in Figures 1-3 and as described in the corresponding figure legends.

\begin{tabular}{cccccccc}
\hline & $\mathrm{A}$ & $\mathrm{B}$ & $\mathrm{C}$ & $\mathrm{D}$ & & & \\
Figure 1 & 0 & 1.5 & 0 & 1.5 & & & Alcohol (\%) \\
& 0 & 0 & 5.0 & 5.0 & & $\mathrm{BaP}(\mu \mathrm{g} / \mathrm{ml})$ \\
$\begin{array}{ccccccc}\text { Figure 2 } \\
\text { (Red) }\end{array}$ & 0 & 0.5 & 1.0 & 1.5 & 2.0 & & Alcohol (\%) \\
& 0 & 0 & 0 & 0 & 0 & & $\mathrm{BaP}(\mu \mathrm{g} / \mathrm{ml})$ \\
$\begin{array}{c}\text { Figure 2 } \\
\text { (Green) }\end{array}$ & 0 & 0.5 & 1.0 & 1.5 & 2.0 & & $\mathrm{Alcohol}(\%)$ \\
& 5.0 & 5.0 & 5.0 & 5.0 & 5.0 & & $\mathrm{BaP}(\mu \mathrm{g} / \mathrm{ml})$ \\
& $\mathrm{N}$ & $\mathrm{N}$ & $\mathrm{N}$ & $\mathrm{N}$ & $\mathrm{Y}$ & $\mathrm{Y}$ & $\mathrm{RA}\left(10^{-8} \mathrm{M}\right)$ \\
Figure 3 & 0 & 1.5 & 0 & 1.5 & 0 & 1.5 & $\mathrm{Alcohol}(\%)$ \\
& 0 & 0 & 5.0 & 5.0 & 5.0 & 5.0 & $\mathrm{BaP}(\mu \mathrm{g} / \mathrm{ml})$ \\
\hline
\end{tabular}

\subsection{Statistical Analysis}

The data were analyzed by a statistical software program that examines the significance of comparison wise error rate by a general linear models procedure. The variable tested for significance in student t-test was CYP1A1 specific activity setting alpha value at 0.05 , confidence limit at $95 \%$, and with 12 degrees of freedom (SAS v. 8; Cary, 
NC).

\section{Results}

\subsection{Individual and Combined Effects of $B[\alpha] P$ and Ethanol on Cell Growth}

The effect of ethanol, $\mathrm{B}[\alpha] \mathrm{P}$ and combinations of these two on the viability and growth of NHK is shown in Figure 1, which presents a composite phase contrast photomicrograph showing the cellular morphology after various 24 hours treatments. Placebo-treated cultures (A) were dosed with $0.1 \%$ DMSO, as were cultures $\mathrm{B}, \mathrm{C}$ and D. In addition, (B) was treated with $1.5 \%$ ethanol, (C) was treated with $5 \mu \mathrm{g} / \mathrm{ml} \mathrm{B}[\alpha] \mathrm{P}$, and (D) was treated with $5 \mu \mathrm{g} / \mathrm{ml} \mathrm{B}[\alpha] \mathrm{P}$ plus $1.5 \%$ ethanol. Since preliminary studies indicated that doses of ethanol above $2 \%$ are toxic, the effect of $1.5 \%$ ethanol was examined in this experiment (B). For all treatments, the cells maintained a close-packed configuration characteristic of post-confluent cultures. All cell cultures did not show any obvious effect between untreated and alcohol-treated cultures. However, cells in the ethanol only treated cultures frequently appeared more rounded with some evidence of mitotic or post-mitotic figures. Morphologically, $\mathrm{B}[\alpha] \mathrm{P}$ only and $\mathrm{B}[\alpha] \mathrm{P}$ plus ethanol-treated cells were not distinguishable from untreated cultures.

Figure 2 is a histogram showing the effects of the various treatments on total cell yields and cell viability. Both $0.5 \%$ and $1 \%$ ethanol treatment stimulated cell growth (red bars). Figure 2 also shows the effect on cell growth of $5 \mu \mathrm{g} / \mathrm{ml}$ of $\mathrm{B}[\alpha] \mathrm{P}$ alone (green bars) or with increasing concentration of ethanol. $\mathrm{B}[\alpha] \mathrm{P}$ treatment was

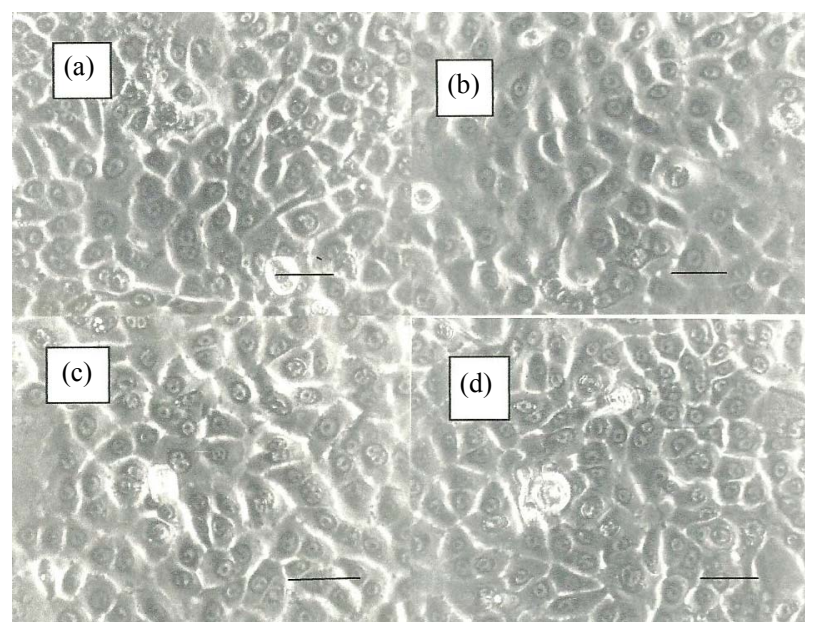

Figure 1. Phase contrast photomicrographs of normal human keratinocyte cultures showing the morphological effect of cultures treated for 24 hours with: (a) Control $(0.1 \%$ DMSO); (b) $1.5 \%$ ethanol (0.1\%DMSO); (c) B $[\alpha]$ P (5 $\mu \mathrm{g} / \mathrm{ml}$. 0.1\%DMSO); (d) B $[\alpha] P(5 \mu \mathrm{g} / \mathrm{ml}, 0.1 \% D M S O+1.5 \%$ ethanol). Total magnification $=1250 \times(5.0 \mu \mathrm{m}$ bar $)$.

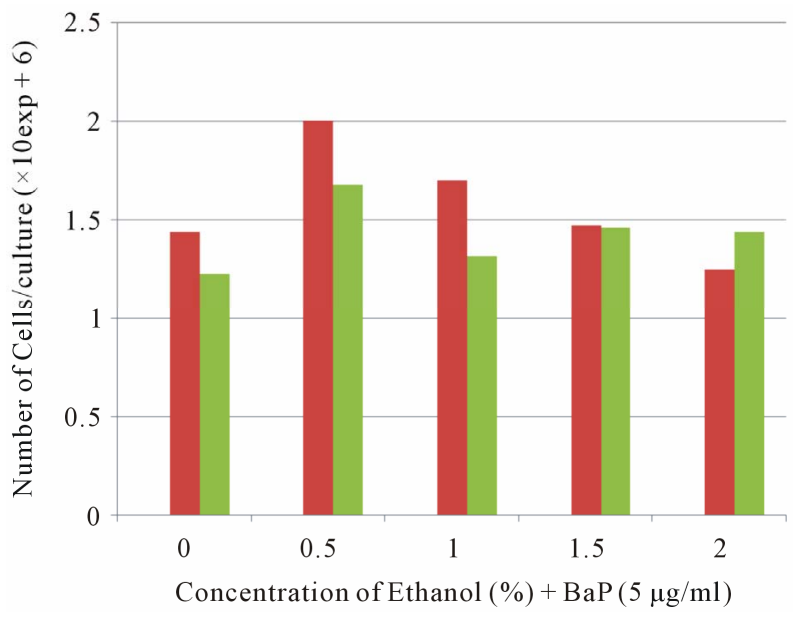

Figure 2. Histogram bar graph showing the effect of individual concentrations of ethanol alone (red bars) and combined ethanol and $B[\alpha] P$ (green bars) on cell growth for 24 hours Bar heights represent the means of triplicate determinations.

only slightly inhibitory compared to untreated controls. All combinations of $\mathrm{B}[\alpha] \mathrm{P}$ with ethanol showed a stimulation of cell growth compared to $\mathrm{B}[\alpha] \mathrm{P}$ only. In a separate viability test, untreated, ethanol-treated, $\mathrm{B}[\alpha] \mathrm{P}$-treated and $\mathrm{B}[\alpha] \mathrm{P}$ plus ethanol-treated cultures all showed $100 \%$ cell viability in Trypan Blue dye exclusion assay ruling out difference in cell viability as possible explanation of the results (data not shown).

\subsection{Effect of $B[\alpha] P$ and Ethanol on CYP1A1 Induction}

Table 1 presents the results of two independent experiments showing the induction of CYP1A1 enzyme activity in NHK cell cultures exposed to $5 \mu \mathrm{g} / \mathrm{ml}$ of $\mathrm{B}[\alpha] \mathrm{P}$ alone compared with $\mathrm{B}[\alpha] \mathrm{P}$ plus $1.5 \%$ ethanol. Experiment 2 was composed of three independent treatment dishes for each of the treatment conditions. The results show that in both experiments 1 and 2 neither untreated control post-confluent cultures (Group A) nor post-confluent cultures exposed to $1.5 \%$ ethanol for 24 hours (Group B) displayed significant basal or constitutive CYP1A1 activity. By contrast, all cultures exposed to either $\mathrm{B}[\alpha] \mathrm{P}$ alone or in combination with ethanol displayed significant induction of CYP1A1 activity. Ethanol in combination with $\mathrm{B}[\alpha] \mathrm{P}$ enhanced the induction of CYP1A1 activity two to threefold greater than the level induced by $\mathrm{B}[\alpha] \mathrm{P}$ only.

\subsection{Effect of Retinoic Acid on Induction and Superinduction of CYP1A1 Activity}

Figure 3 present the results of several independent trials testing the effect of all-trans retinoic acid on $\mathrm{B}[\alpha] \mathrm{P}$-in- 
Table 1. Effects of benzo[ $\alpha]$ pyrene and ethanol on levels of aryl hydrocarbon hydroxylase in cultured human keratinocytes.

\begin{tabular}{|c|c|c|c|c|c|}
\hline \multirow{3}{*}{ Group } & \multirow{3}{*}{ Treatment $^{1}$} & \multicolumn{4}{|c|}{ Experiment } \\
\hline & & \multicolumn{2}{|l|}{1} & \multicolumn{2}{|l|}{2} \\
\hline & & $\mathrm{AHH}(\mathrm{pmol} / 30 \mathrm{~min} / \mathrm{mg})$ & $(\mathrm{N})$ & AHH (pmol/30min/mg) & $(\mathrm{N})$ \\
\hline A & Control & $\mathrm{NA}^{2}$ & 1 & NA & 3 \\
\hline B & Ethanol & NA & 1 & NA & 3 \\
\hline $\mathrm{C}$ & $\mathrm{B}[\alpha] \mathrm{P}$ & 61 & 1 & $179 \pm 45$ & 3 \\
\hline $\mathrm{D}$ & $\mathrm{B}[\alpha] \mathrm{P}+$ Ethanol & 98 & 1 & $307 \pm 41^{3}$ & 3 \\
\hline
\end{tabular}

${ }^{1}$ Normal human epidermal keratinocytes were grown in serum-free medium containing $100 \mu \mathrm{M}$ ethanolamine, $100 \mu \mathrm{M}$ phosphoethanolamine, $0.5 \mu \mathrm{M}$ hydrocortisone, $5 \mu \mathrm{g} / \mathrm{ml}$ insulin, $10 \mu \mathrm{g} / \mathrm{ml}$ EGF and $0.25 \%$ bovine pituitary extract. Cultures were seeded at $2 \times 10^{3}$ cells per cm ${ }^{2}$ and refed fresh medium every 48 hours until they reached confluence. Non dividing post-confluent cultures (approximately $2 \times 10^{6}$ cells per dish) were treated with A, $0.1 \%$ DMSO; B, $1.5 \%$ ethanol; C, $20 \mu \mathrm{B}[\alpha] \mathrm{P}$, and D, $1.5 \%$ ethanol $+20 \mu \mathrm{M} \mathrm{B}[\alpha] \mathrm{P}$. Groups B, C, and D were also treated with $0.1 \%$ DMSO. ${ }^{2}$ No measureable activity, ${ }^{3}$ Significantly different from Group $\mathrm{C}$ by two-tailed student $\mathrm{t}$ test $(\mathrm{p}<0.05)$.

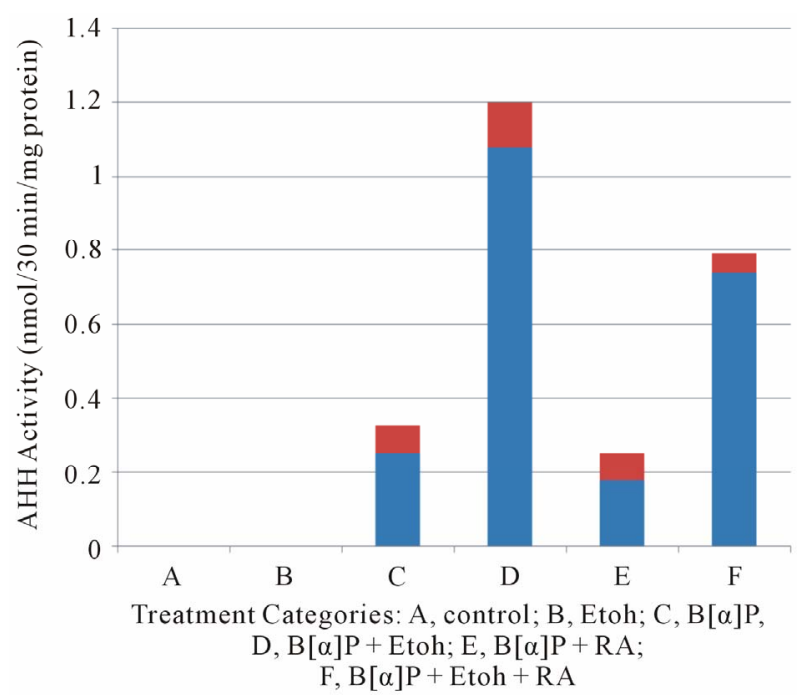

Figure 3. Histogram bar graph showing the effect of various treatments on the induction of AHH activity in post-confluent cultures of normal human keratinocytes. (A) control,

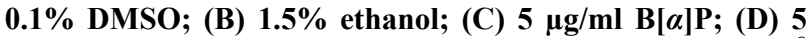
$\mu \mathrm{g} / \mathrm{ml} \mathrm{B}[\alpha] \mathrm{P}$ plus $1.5 \%$ ethanol; (E) pretreat with $1 \times 10^{-8}$ M RA for $30 \mathrm{~min}$, then 24 hours with $5 \mu \mathrm{g} / \mathrm{ml} \mathrm{B}[\alpha] \mathrm{P}$; and (F) pretreat with $1 \times 10^{-8} \mathrm{M}$ RA for 30 min, then 24 hours with $5 \mu \mathrm{g} / \mathrm{ml} \mathrm{B}[\alpha] \mathrm{P}$ plus $1.5 \%$ ethanol. Bar heights represent the mean values for four replicate determinations (blue bars) \pm S.E (red bars).

duced CYP1A1 activity as well as on the enhanced-induction of CYP1A 1 activity by $\mathrm{B}[\alpha] \mathrm{P}$ in combination with ethanol. As shown above $\mathrm{B}[\alpha] \mathrm{P}$ alone (Group $\mathrm{C}$ ) induces a significant increase in CYP1A1 activity over the untreated and ethanol only treated controls $(p<0.05)$. Once again we observed an enhanced CYP1A1 activity in the $\mathrm{B}[\alpha] \mathrm{P}$ plus ethanol cultures (Group D) $(\mathrm{p}<0.05)$. However, pre-treatment of post-confluent cultures for 30 minutes with $1 \times 10^{-8} \mathrm{M}$ t-RA inhibited ethanol-enhanced-induction by about $25 \%(\mathrm{p}<0.05)$. The analysis showed that Group $\mathrm{C}$ was significantly different from
Groups A, B, D and F $(\mathrm{p}<0.05)$ but not group E. Group $\mathrm{D}$ is significantly different from Groups A, B, C, E and F $(\mathrm{p}<0.05)$.

\section{Discussion}

We examined the induction of CYP1A1 activity by $\mathrm{B}[\alpha] \mathrm{P}$ in cultures of NHK. In particular, to exclude interfering effects of uncharacterized serum components we performed these studies in a well characterized serum-free medium system under controlled protein growth factor and low calcium serum-free medium conditions. These culture conditions result in predominantly growtharrested NHK cultures with a uniform confluent monolayer of substantially undifferentiated basal cells. Thus, in the absence of serum and other confounding culture additives, we observed no obvious visual evidence on $\mathrm{B}[\alpha] \mathrm{P}$ and $\mathrm{B}[\alpha] \mathrm{P}$ in combination with ethanol on cell morphology. By contrast, low doses addition of alcohol stimulated an increase in cell density. Addition of $\mathrm{B}[\alpha] \mathrm{P}$ to confluent-induced growth-arrested NHK cultures yielded no change cell viability by Trypan Blue dye exclusion test, and no apparent change in cell morphology was detected by contrast microscopy in living cultures. Addition of $1.5 \%$ ethanol along with $\mathrm{B}[\alpha] \mathrm{P}$ also had no visible effect of culture morphology but did result in higher total cells per culture at the tested amounts of ethanol. Any possible toxic effect of added $\mathrm{B}[\alpha] \mathrm{P}$ alone appears to be negated in the presence of the low amounts of added alcohol. There was no detectable level of CYP1A1 activity in growth-arrested keratinocytes either in the absence or presence of $1.5 \%$ ethanol. By contrast, $\mathrm{B}[\alpha] \mathrm{P}$ induces significant levels of CYP1A1 activity in growth-arrested keratinocytes within 24 hours, and occurs without any significant increase in cell proliferation. Unexpectedly, the combined addition of $1.5 \%$ ethanol and $15 \mu \mathrm{g}$ of $\mathrm{B}[\alpha] \mathrm{P}$ to serum-free growth-arrested keratinocytes resulted in enhanced induction of CYP1A1 ac- 
tivity over $\mathrm{B}[\alpha] \mathrm{P}$ alone. We designate this effect of ethanol on enhanced level of CYP1A1 activity super induction. Super induction of CYP1A1 activity in human epidermal cells by alcohol fits with abundant data of a synergistic effect of alcohol and $\mathrm{B}[\alpha] \mathrm{P}$ on increased oral cancer risk of combined alcohol consumption and exposure to tobacco carcinogen such as $\mathrm{B}[\alpha] \mathrm{P}$.

We next examined the effect of the retinoid, all t-RA, on $\mathrm{B}[\alpha] \mathrm{P}$ induction. We and others previously demonstrated a chemoprevention effect of retinoids in carcinogenesis $[23-25,28-30]$. Thus, retinoid can reverse $\mathrm{B}[\alpha] \mathrm{P}$ induced squamous metaplasia, prevent papilloma formation, and block $\mathrm{B}[\alpha] \mathrm{P}$ induced forestomach tumors in animal study [23-25]. There is a concern that ethanol is merely acting to increase the permeability of NHK cells to $\mathrm{B}[\alpha] \mathrm{P}$, which indirectly activates $\mathrm{CYP} 1 \mathrm{~A} 1$ receptors. This possibility has been explored earlier [26]. Kuratsume et al. reported that both ethanol and retinoids have marked effect on membrane diffusibility [26]. Here, we showed here that t-RA pre-treatment actually reverses ethanol enhanced CYP1A1 induction. It seems unlikely that t-RA would affect membrane diffusion of ethanol through epidermal cell membranes. It argues against ethanol simply acting as a solubility enhancer for $\mathrm{B}[\alpha] \mathrm{P}$.

Our results confirm the hypothesis that retinoid pretreatment mediate induction cytochrome P450 oxidases at the cellular level in growth-arrested keratinocytes. We propose that the combined effects of ethanol and $\mathrm{B}[\alpha] \mathrm{P}$ on CYP1A1 inducibility may partially account for the known alcohol enhanced risk of tobacco-associated oral cancer, while the reversal by t-RA on ethanol enhanced CYP1A1 induction is consonant with the known mitigating effect of retinoids on oral carcinogenesis.

\section{Acknowledgements}

We wish to thank Gloria Triggs for her expert animal surgical services. The author especially acknowledges assistance with the biochemical assays performed by Dr. Dennis J. McCarthy.

\section{REFERENCES}

[1] L. Loeb and C. Harris, "Advances in Chemical Carcinogenesis: A Historical Review and Prospective," Cancer Research, Vol. 68, No. 17, 2008, pp. 6863-6890. doi:10.1158/0008-5472.CAN-08-2852

[2] X. Ding and L. Kaminski, "Human Extrahepatic Cytochromes P450: Function in Xenobiotic Metabolism and Tissue-Selective Chemical Toxicity in the Respiratory and Gastrointestinal Tracts," Annual Review of Pharmacology and Toxicology, Vol. 43, 1993, pp. 149-173. doi:10.1146/annurev.pharmtox.43.100901.140251

[3] Q. Ma and A. Lu, "CYP1A Induction and Human Risk Assessment: An Evolving Tale of in Vitro and in Vivo
Studies," Drug Metabolism and Disposition, Vol. 3, No. 5, 2007, pp. 1009-1016. doi:10.1124/dmd.107.015826

[4] K. Tatematsu, A. Koide, M. Hirose, A. Nishikawa and Y. Mori, "Effect of Cigarette Smoke on Mutagenic Activation of Environmental Carcinogens by Cytochrome P450 2A8 and Inactivation by Glucuronidation in Hamster Liver," Mutagenesis, 2010.

[5] T. Shimada, Y. Oda, E. Gillam, F. Guengerich and K. Inoue, "Metabolic Activation of Polycyclic Aromatic Hydrocarbons and Other Procarcinogens by Cytochromes P450 1A1 and P450 1B1 Allelic Variants and Other Human Cytochromes $\mathrm{P} 450$ in Salmonella typhimurium NM2009," Drug Metabolism and Disposition, Vol. 29, 2001, pp. 1176-1182.

[6] M. Finnen, C. Lawrence and S. Shuster, "Human Skin Aryl Hydrocarbon Hydroxylase," British Journal of Dermatology, Vol. 110, No. 3, 1984, pp. 339-342. doi:10.1111/j.1365-2133.1984.tb04640.x

[7] J. Reiners Jr., A. Cantu and A. Pavone, "Modulation of Constitutive Cytochrome P-450 Expression in Vivo and in Vitro in Murine Keratinocytes as a Function of Differentiation and Extracellular $\mathrm{Ca}^{2+}$ Concentration," Proceedings of the National Academy of Sciences, Vol. 87, No. 5, 1990, pp. 1825-1829. doi:10.1073/pnas.87.5.1825

[8] J. Guo, R. Brown, C. Rothwell and I. Bernstein, "Levels of Cytochrome P-450-Mediated Aryl Hydrocarbon Hydroxylase (AHH) Are Higher in Differentiated than in Germinative Cutaneous Keratinocytes," Journal of Investigative Dermatology, Vol. 94, No. 1, 1990, pp. 86-93. doi:10.1111/1523-1747.ep12873939

[9] T.Kometani, I. Yoshino, N. Miura, H. Okazaki, T. Ohba, T. Takenaka, F. Shoji, T. Yano and Y. Maehara, "Benzo[a]pyrene Promotes Proliferation of Human Lung Cancer Cells by Accelerating the Epidermal Growth Factor Receptor Signaling Pathway," Cancer Letters, Vol. 278, No. 1, 2009, pp. 27-33. doi:10.1016/j.canlet.2008.12.017

[10] W. Jiang, L. Wang, S. Kondraganti, I. Fazili, X. Couroucli, E. Felix and B. Moorthy, "Disruption of the Gene for CYP1A2, Which Is Expressed Primarily in Liver, Leads to Differential Regulation of Hepatic and Pulmonary Mouse CYP1A1 Expression and Augmented Human CYP1A1 Transcriptional Activation in Response to 3Methylcholanthrene in Vivo," Journal of Pharmacology and Experimental Therapeutics, Vol. 201, 2010, pp. 369379. doi:10.1124/jpet.110.171173

[11] I. Khan, D. Bickers, T. Haqqi and H. Mukhtar, "Induction of CYP1A1 mRNA in Rat Epidermis and Cultured Human Epidermal Keratinocytes by Benz(a)Anthracene and Beta-Naphthoflavone," Drug Metabolism and Disposition, Vol. 20, No. 5, 1992, pp. 620-624.

[12] B. Allen-Hoffmann and J. Rheinwald, "Polycyclic Aromatic Hydrocarbon Mutagenesis of Human Epidermal Keratinocytes in Culture," Proceedings of the National Academy of Sciences, Vol. 81, No. 24, 1984, pp. 78027806. doi:10.1073/pnas.81.24.7802

[13] M. Stampfer and J. Bartley, "Induction of Transformation and Continuous Cell Lines from Normal Human Mammary Epithelial Cells after Exposure to Benzo[a]pyrene," 
Proceedings of the National Academy of Sciences, Vol. 82, No. 8, 1985, pp. 2394-2398. doi:10.1073/pnas.82.8.2394

[14] J. Park, J. Muscat, Q. Ren, S. Schantz, R. Harwick, J. Stern, V. Pike, J. Richie Jr and P. Lazarus, "CYP1A1 and GSTM1 Polymorphisms and Oral Cancer Risk," Cancer Epidemiology Biomarkers \& Prevention, Vol. 6, No. 10, 1997, pp. 791-797.

[15] B. Rodu and C. Jansson, "Smokeless Tobacco and Oral Cancer: A Review of the Risks and Determinants," Critical Reviews in Oral Biology \& Medicine, Vol. 15, No. 5, 2004, pp. 252-263. doi:10.1177/154411130401500502

[16] N. Maserejian, K. Joshipura, B. Rosner, E. Giovannucci and A. Zavras, "Prospective Study of Alcohol Consumption and Risk of Oral Premalignant Lesions in Men," Cancer Epidemiology, Biomarkers \& Prevention, Vol. 15, No. 4, 2006, pp. 774-781. doi:10.1158/1055-9965.EPI-05-0842

[17] M. Sporn, N. Dunlop, D. Newton and J. Smith, "Prevention of Chemical Carcinogenesis by Vitamin A and Its Synthetic Analogs (Retinoids)," The FASEB Journal, Vol. 35, 1976, pp. 1332-1338.

[18] G, Zhou G, M. Richardson, I. Fazilil, J. Wang, K. Donnelly, F. Wang, B. Amendt and B. Moorthy, "Role of Retinoic Acid in the Modulation of Benzo(a)pyrene-DNA Adducts in Human Hepatoma Cells: Implications for Cancer Prevention," Toxicology and Applied Pharmacology, Vol. 249, No. 3, 2010, pp. 224-230.

[19] P. Mrass, M. Rendl, M. Mildner, F. Gruber, B. Lengauer, C. Ballaun, L. Eckhart and E. Tschachler, "Retinoic Acid Increases the Expression of p53 and Proapoptotic Caspases and Sensitizes Keratinocytes to Apoptosis: A Possible Explanation for Tumor Preventive Action of Retinoids," Cancer Research, Vol. 64, No. 18, 2004, pp. 6542-6548. doi:10.1158/0008-5472.CAN-04-1129

[20] K. Bogos, F. Renyi-Vamos, G. Kovacs, J. Tovari and B. Dome, "Role of Retinoic Receptors in Lung Carcinogenesis," Journal of Experimental \& Clinical Cancer Research, Vol. 27, No. 18, 2008.

[21] J. Wille and D. Chopra, "Reversal by Retinoids of Keratinization Induced by Benzo[alpha]pyrene in Normal Hamster Tracheal Explants: Comparison with the Assay Involving Organ Culture of Tracheas from Vitamin ADeficient Hamsters," Cancer Letters, Vol. 40, No. 3, 1988, pp. 35-46. doi:10.1016/0304-3835(88)90082-1

[22] D. Ramya, M. Siddikuzzaman and V. Berlin Grace,
"Chemoprotective Effect of All-Trans Retinoic Acid (ATRA) on Oxidative Stress and Lung Metastasis Induced by Benzo(a)pyrene," Immunopharmacology and Immunotoxicology, Vol. 34, No. 2, 2012, pp. 317-325. doi:10.3109/08923973.2011.604087

[23] J. Wille Jr., M. Pittelkow, G. Shipley and R. Scott, "Integrated Control of Growth and Differentiation of Normal Human Prokeratinocytes Cultured in Serum-Free Medium: Clonal Analyses, Growth Kinetics, and Cell Cycle Studies," Journal of Cellular Physiology, Vol. 121, No. 1, 1984, pp. 31-44. doi:10.1002/jcp.1041210106

[24] M. Pittelkow, J. Wille Jr. and R. Scott, "Two Functionally Distinct Classes of Growth Arrest States in Human Prokeratinocytes That Regulate Clonogenic Potential," Journal of Investigative Dermatology, Vol. 86, 1986, pp. 410417. doi:10.1111/1523-1747.ep12285684

[25] Q. Ren, S. MurphyA. Dannenberg, J. Park, T. Tephly and P. Lazarus, "Glucuronidation of the Lung Carcinogen 4(Methylnitrosamino)-1-(3-pyridyl)-1-butanol by Rat UDTGlucuronosyltransferase 2B1," Drug Metabolism and Disposition, Vol. 27, 1986, pp. 1010-1016.

[26] G. Bowden, T. Slaga, B. Shapas and R. Boutwel, "The Role of Aryl Hydrocarbon Hydroxylase in Skin Tumor Initiation by 7,12-Dimethylbenz(a)anthracene and 1,2,5,6Dibenzanthracene Using DNA Binding and Thymidine3H Incorporation into DNA as Criteria," Cancer Research, Vol. 34, No. 10, 1974, pp. 2634-2642.

[27] O. Lowry, N. Rosebrough, A. Farr and R. Randall, "Protein Measurement with the Folin Phenol Reagent," Journal of Biological Chemistry, Vol. 193, No. 1, 1951, pp. 265-275.

[28] A. Verma , H. Rice, B. Shapas and R. Boutwell, "Inhibition of 12-O-Tetradecanoylphorbol-13-Acetate-Induced Ornithine Decarboxylase Activity in Mouse Epidermis by Vitamin A Analogs (Retinoids)," Cancer Research, Vol. 38, No. 3, 1978, pp. 793-801.

[29] U. Goswami, and N. Sharma, "Efficiency of a Few Retinoids and Carotenoids in Vivo in Controlling Benzo[a]pyrene-Induced Forestomach Tumour in Female Swiss Mice," British Journal of Nutrition, Vol. 94, No. 4, 2005, pp. 540-543. doi:10.1079/BJN20051484

[30] M. Kuratsune, S. Kohchi and H. Horie, "Carcinogenesis in the Esophagus. I. Penetration of Benzo(a)pyrene and Other Hydrocarbons into the Esophageal Mucosa," Gann, Vol. 56, 1965, pp. 177-187. 